MYKOL ROMERIO
UNIVERITEIAS

\title{
FAIR PRICE IN SQUEEZE-OUT TRANSACTIONS
}

\author{
Feliksas Miliutis \\ Mykolas Romeris University, Faculty of Law \\ Department of Commercial Law \\ Ateities 20, LT-08303 Vilnius, Lithuania \\ Telephone: $(+370) 61223312$ \\ E-mail: f.miliutis@glimstedt.lt
}

Received 17 January, 2012; accepted 20 July, 2013

doi:10.13165/SMS-13-5-3-06

\begin{abstract}
Squeeze-out" is considered as a situation, where a controlling shareholder exercises his legal right to oblige the minority shareholders of a targeted listed company to sell their shares of the target to him, which brings the target company private. This article discusses the topic of fair squeeze-out compensation from both European and US (Delaware) perspectives. The author of this paper argues that though legal settings of squeeze-outs and determination of fair compensation of squeeze-out differs from country to country, some general insights might be identified that in their own turn would allow to identify main practical and theoretical problems of protection of minority/majority shareholders' rights related with the fair squeeze-out compensation.
\end{abstract}

Keywords: squeeze-out, takeover-bid, merger, fair price, fair value.

\section{Introduction}

For the purposes of this article, the term 'squeeze-out" is considered as a situation, where a controlling shareholder exercises his legal right to oblige the minority shareholders of a targeted listed company to sell their shares of the target to him, 
which brings the target company private ${ }^{1}$. Conflict between the interests of minority and majority shareholders is one of the main elements that form the core of problems analyzed by the theory of corporate law ${ }^{2}$. The squeeze-out, as it is understood for the purposes of this article, is the classical example of such contraposition. Striking the right balance between the interests of minority/majority shareholders or, in other categories, interests of minority shareholders and facilitation of the efficient takeover market is one of the most troublesome tasks for the legislature and the judiciary dealing with the squeeze-out cases ${ }^{3}$. This seems especially true with regard compensation paid to the expelled shareholders in squeeze-out transactions. Application of too stringent (prominority) criteria for the determination of a fair price in squeeze-outs may reduce the number of value creating takeover transactions. However, the introduction of too lenient requirements to validate the squeeze-out price as "fair" may encourage opportunistic behavior of controlling shareholders and subsequently lead to the initiation of transactions to the detriment of minority shareholders.

Legal acts of most European and non-European jurisdictions do not provide elaborate and direct procedures for determination of adequate compensation in the squeeze-outs (at least it seems true for the legal system of Germany ${ }^{4}$, Delaware ${ }^{5}$, Canada ${ }^{6}$, Belgium, France, the UK and the Netherlands ${ }^{7}$ ). The lack of legal certainty (which, it can be argued, is not necessarily a shortcoming, as 'the rule of reason' approach might be more appropriate to judge the cases, each having its' own individual features) also contributes to the number of problematic issues related to the determination of appropriate compensation in the squeeze-out transactions. Due to the lack of legal certainty and the

1 It should be noted that some authors (see Ventoruzzo, M. Freeze-Outs: Transcontinental Analysis and Reform Proposals. Virginia Journal of International Law. 2010, 50(4): 842-917, 842, footnote 1) claim that the term "squeeze-out" should refer to the cases when management of a company seeks to extract private benefits from the company and that the term "freeze-out" should be used to define buy-outs of the remaining shares in the listed companies resulting in their de-listing. Though in scholarly literature terms "squeezeout", "freeze-out" or "buy-out" occasionally are used interchangeably, the author of this paper will keep to the European tradition and use the term "squeeze out".

2 Kraakman, R. et al. The Anatomy of Corporate Law: A Comparative and Functional Approach. Oxford: Oxford University Press, 2004.

3 Burkart, M. and Panunzi, F. Law working paper No 10/2003: Mandatory Bids, Squeeze-out, Sell-out and the Dynamics of the Tender Offer Process. 2003, Stockholm Institute of Transitional Economics \& Department of Finance, Stockholm School of Economics and CEPR [interactive]. [accessed on 10-08-2011]. <http://ssrn. com/abstract $=420940>$, p. 6 .

4 Elsland, S. and Weber, M. Squeeze-outs in Germany: Determinants of the Announcement Effects [interactive]. [accessed on 10-08-2011]. <http://www.uni-tuebingen.de/dgf/program/CPaper137.pdf>, p. 2.

5 See, e. g., Subramanian, G. Fixing Freezeouts. Yale Law Journal. 2005, 115: 2-70.

6 Hunter, C. and Potter, K. Legal and Practical Issues for Business Valuation in Shareholders Agreements and Minority Shareholder Rights. Paper presented to the Canadian Institute of Chartered Business Valuators Calgary Chapter on October 0 (wrong day), 1997 [interactive]. [accessed on 10-08-2011]. <http://www. macleoddixon.com/documents/Business_Valuation_in_Shareholders_Agreements_and_Miniority_Shareholder_Rights.pdf $>$, p. 8 .

7 See Van der Elst, C. and Van den Steen, L. Balancing the Interests of Minority and Majority Shareholders: A Comparative Analysis of Squeeze-out and Sell-out Rights. ECFR 4/2009, p. 391-439. 
above-mentioned circumstances, it is not surprising that litigation on the issue of the fair price (on re-evaluation of the squeeze-out price) is extensive ${ }^{8}$.

The object of this paper is legal regulation of the "fair" price in the squeeze-out transactions. Mainly, the legal regulation of Delaware, EU-level legal regulation and regulation of some EU member states will be considered ${ }^{9}$. The author of this paper argues that though legal settings of the squeeze-outs and the determination of fair compensation of the squeeze-out differs from country to country, some general insights might be identified. Following that, by employing comparative strategy and using qualitative literature analysis as the main method as well as applying traditional legal techniques of formal logic (systematical analysis, reduction and deduction), the author of this paper will try to identify generic features of the legal regulation of the "fair" price in the squeeze-out transactions and evaluate such features with regard interests of minority and majority shareholders by identifying the main practical and theoretical problems.

To the best knowledge of the author, the issue of the fair squeeze-out compensation on EU and EU member states level has been most recently addressed by Kaisanlahti ${ }^{10}$, who considered the role of bid prices in determining the fair value of securities in postbid squeeze-outs ${ }^{11}$, and indirectly by Van Der Elst and Van Den Steen ${ }^{12}$, who addressed the issue whether general legal regulation of squeeze-out right in some EU member states is equivalent with regard interests of minority shareholder ${ }^{13}$, and also Ventoruzzo ${ }^{14}$, who examined the differences between European and US approaches towards general regulation of the squeeze-outs ${ }^{15}$. In the US, the bulk of recent scholarly works directly or indirectly addressing the issue of the fair compensation in the squeeze-outs is even more extensive ${ }^{16}$. However, none of this literature directly aims to derive common insights regarding fair compensation from US/EU/EU member states perspective and provide their evaluation with regard interests of minority and majority shareholders by identifying the main practical and theoretical problems. In the wake of an increasing

$8 \quad$ Ibid.; Rathausky, U. Squeeze-out in Deutschland: Eine Empirische Untersuchung zu An-fechtungsklagen und Spruchverfahren, Die Aktiengesellschaft, R24-R26. 2004.

9 Legal regulation of Delaware is considered as it is generally valued as the most attractive corporate environment in the United States of America, i.e. more than 50\% of all American companies trading their shares in regulated markets have opted for the law of Delaware (See http://corp.delaware.gov/). Delaware courts have dealt with a significant number of squeeze-out cases concerning the issue of "fair" price (or "fair" value), therefore, its experience on the issue will indisputably provide valuable insights when combined with the EU level and EU member states level approach.

10 Kaisanlahti, T. When Is a Tender Price Fair in the Squeeze-out? European Business Organization Law Review. 2007, 8: 497-519.

11 Ibid, p. 497.

12 Van der Elst, C. and Van den Steen, L., supra note 7.

13 Ibid., p. 393.

14 Ventoruzzo, M., supra note 1.

15 Ibid., p. 885.

16 Hamermesh, L. A. and Wachter, M. L. Rationalizing Appraisal Standards in Compulsory Buyouts. 50 B.C. L. Rev. 2009: 1021-1068; Hamermesh, L. A. and Wachter, M. L. The Short and Puzzling Life of the Implicit Minority Discount. 156 U. Pa. L. Rev. 2007-2008, 2: 1-61 and other. 
number of transcontinental and cross border mergers and acquisitions ${ }^{17}$, where different legal regimes apply to a target company and a bidder, the discussion offered by this paper seems to be even more topical.

This article starts with a brief introduction to different squeeze-out legal regimes, which is necessary to frame the further discussion. The article continues to introduce the reader with a legal framework on the fair squeeze-out compensation. Subsequently, the answers to the questions which price is considered as fair and how it is determined are presented and, finally, the conclusions are drawn.

\section{Roadmap}

Though it can be reasonably assumed that the rationales for going private are the same in both the EU and the US, i.e. avoidance of agency costs and compliance with listing-related reporting and other requirements ${ }^{18}$, economies of scale ${ }^{19}$, constant underpricing of publicly traded shares ${ }^{20}$, improved debt-to-equity ratio and tax mitigation ${ }^{21}$, etc., legal options to execute a squeeze-out are different.

In the US (Delaware), currently there are two legal options for a majority shareholder to implement the squeeze-out. The first is a statutory "long-form" merger"22, where subject to a prior opinion of the management board of both merging companies ${ }^{23}$ and majority of minority (shareholders) approval ${ }^{24}$ the forced-out shareholders are offered compensation in cash or in shares of the controlling company. The second option is the so called "two-tier" squeeze-out ${ }^{25}$, which is a combination of a properly structured

17 See U.N. Conference on Trade and Development. World Investment Report 2006. FDI from Developing and Transition Economies: Implication for Development. 2006 [interactive]. [accessed on 10-08-2011]. <http:// www.unctad.org/en/docs/wir2006_en.pdf>.

18 See Report of the High Level Group of Company Law Experts on Issues Related to Takeover Bids. 10 January, 2002, Brussels [interactive]. [accessed on 10-08-2011]. <http://ec.europa.eu/internal_market/ company/docs/takoverbids/report_en.pdf>, p. 60; Regner, W. D. Going Private in the US. International Financial Law Review, Supplement: The 2006 Guide to Mergers and Acquisitions. 2006 [interactive]. [accessed on 10-08-2011]. < http://www.iflr.com/?Page=17\&ISS=21679\&SID=624573>; Pritchard, A. C. Tender Offers by Controlling Shareholders: The Specter of Coercion and Fair Price. Berkeley Business Law Journal. 2004, 1(83): 83-111, 83.

19 Pinto, A. R. and Branson, D. M. Understanding Corporate Law. 2nd edition. New York: M. Bender, 2004, p. 260.

20 Ventoruzzo, M., supra note 1, p. 848.

21 Lehn, K. and Poulsen, A. Free Cash Flow and Stockholder Gains in Going Private Transactions. 44 J. Fin. 1989, 771; Van der Elst, C. and Van Den Steen, L. Working Paper: Opportunities in the M\&A Aftermarket: Squeezing out and Selling out. Financial Law Institute, University Gent, 2006, p. 9.

22 Delaware General Corporation Law [interactive]. [accessed on 10-08-2011]. <http://delcode.delaware.gov/ title8/c001/index.shtml - P-1_0>, Art. 251.

23 Ibid., Art. 251 (b).

24 Ibid., Art. 251 (c).

25 Furlow, C. V. Back to Basics: Harmonizing Delaware's Law Governing Going Private Transactions. 40 Akron L. Rev. 2007, 85: 85 
first-tier tender offer ${ }^{26}$ and a second-tier "short-form" merger" ${ }^{27}$, which derives from a statutory right of a mother company to effect a merger with its daughter company, in which it holds at least $90 \%$ of shares ${ }^{28}$. A tender offer is addressed directly to the target's minority shareholders and the board of the target company is not required to approve the terms and conditions of the offer. ${ }^{29}$ However, a committee of independent directors would be formed to give their opinion on conditions of the tender offer, i.e. to recommend either rejecting or accepting the offer, stay neutral or state that they are unable to take a position on the offer. ${ }^{30}$ In the second-tier, shares of the controller are offered as a compensation for dissenting shareholders. ${ }^{31}$ Minority shareholders, who did not bid their shares in the first-tier tender offer, receive a compensation for their shares after the second-tier merger is completed.

The "long-form" merger creates a conflict of interests' situation, as it is the controlling shareholder who enjoys control with regard boards of the acquiring company and the target ${ }^{32}$. This poses an inherent conflict of interests, as the controlling shareholder will have the power to influence both parties to the transaction and thus also the consideration offered to the minority shareholders for their shares. ${ }^{33}$ However, the first-tier tender offer in the "two-tier" squeeze-out transaction is generally considered as not coercive ${ }^{34}$, i.e. the controller would obtain the right to enter into the second phase, where the minority is actually squeezed-out only if a considerable part or the minority shareholders would bid their shares in the first phase ${ }^{35}$. As ninety percent is the critical threshold in a tender offer squeeze-out, the controller typically conditions its offer on getting to 90 percent control ${ }^{36}$.

As it has been already mentioned, the conflict of interests is inherent to the "longform" merger, whereas such conflict in a case of the two-tier squeeze out (first-tier tender offer) is absent. Moreover, a board of directors has no statutory role with regard to the first-tier tender offer, though it is otherwise in the case of the "long-form" merger".

26 Here, as in other cases, a tender offer means a public offer addressed to all shareholders of a target company in order to gain sufficient control of the target company - in this case, at least $90 \%$ of target's shares (see Aronstam, B. R.; Balotti, R. F. and Rehbock, T. Delaware's Going Private Dilemma: Fostering Protections for Minority Shareholders in the Wake of Siliconix and Unocal Exploration. Business Lawyer. 2003, 58: 519-558., 526).

27 Abrams, K. G. and Laster, T. New Delaware Rules for Going Private Transactions. Insights. 2005, 19(7): 9-13, 9 .

28 Delaware General Corporation Law, supra note 22, section 253.

29 Iacono, C. Tender Offers and Short-Form Mergers by Controlling Shareholders Under Delaware Law: The '800-Pound Gorilla' Continues Unimpeded - In re Pure Resources, Inc., Shareholders Litigation. Delaware Journal of Corporate Law. 2003, 28: 645-689; 651-652.

30 Subramanian, G., supra note 5, p. 17.

31 Iacono, C., supra note 29, p. 655.

32 Subramanian, G., supra note 5, p. 9.

33 Ibid.

34 Aronstam, B. R.; Balotti, R. F. and Rehbock, T., supra note 26, p. 526.

35 Subramanian, G., supra note 5, p. 17-18.

36 Subramanian, G., supra note 5, p 18.

37 In re Siliconix Inc. Shareholders Litigation, No. CV-A-18700, 2001 WL 716787 (Del. Ch. June 19, 2001), para. 7. 
These dissimilarities have led to different standards of judicial review to the squeezeouts based on the choice of transactional form ${ }^{38}$, i.e. the "long-form" merger would be reviewed by Delaware courts under the "entire fairness test" 39 , which encompasses fair dealing and fair price ${ }^{40}$, and the "two-tier" squeeze-out would not, the only option for the minority being the right of appraisal ${ }^{41}$.

On the EU level, squeeze-out right was introduced by Thirteenth Company Law Directive on Takeover Bids ${ }^{42}$ (hereinafter - the Directive). The Directive introduced (as some authors call it $)^{43}$ the take-over squeeze-out, i.e. the squeeze-out, which is available to the bidder only after the tender offer (also referred to as a takeover bid - a general bid for shares, which are admitted to trading on a regulated market ${ }^{44}$ ), which is now the minimum standard in the EU member states.

The Directive mandates that the member states provide the bidders with the right to squeeze out the minority shareholders within a three-month period, immediately following the end of the acceptance period "in one of the following situations": (a) the bidder holds no less than $90 \%$ of the target's securities and $90 \%$ of the target's voting rights (member states may increase the threshold up to 95\%), or (b) at the bid's closing the bidder acquires $90 \%$ of the target's securities, which it did not already hold at the commencement of the offer. As some authors claim, these options are alternatives and represent the account of national traditions in the member states ${ }^{45}$, i.e. option (a) follows the continental tradition, whereas option (b) derives from UK company law ${ }^{46}$.

Despite the harmonization efforts on the EU, national legislators still struggle to provide new or retain the existing pre-Directive rules on the squeeze-out rights, which are outside the limited scope of the Directive ${ }^{47}$, i.e. most of the EU member states allow the so called "corporate squeeze-outs" 48 , e.g. the EU member states like Belgium, France, the Netherlands, Germany ${ }^{49}$ and Czech Republic ${ }^{50}$ allow the squeeze-outs regardless

38 Subramanian, G., supra note 5, p. 7.

39 Aronstam, B. R.; Balotti, R. F. and Rehbock, T., supra note 26, p. 523.

40 See Weinberger v. UOP, Inc., 457 A.2d 701 (Del. 1983) at 711 . According to the court, fair dealing focuses on the process and the conduct of the controlling shareholder, including "how the transaction was timed, initiated, structured, negotiated, disclosed to the directors, and how the approvals of the directors and the stockholders were obtained". Fair price, on the other hand, concerns the economic and financial aspects of the transaction: its market values, assets, future prospects and earnings. The court stated that although the entire fairness test had two elements, it was not bifurcated and the transaction had to be examined as a whole.

41 Gilson, R. J. and Gordon, J. N. Controlling Controlling Shareholders. University of Pennsylvania Law Review. 2003, 152(785): 785-843, 818-819.

42 European Parliament and Council Directive of 21-04-2004 No. 2004/25/EC on Takeover Bids. OJ L 2004, 142: 12-23.

43 See, e. g., Van der Elst, C. and Van den Steen, L., supra note 7, p. 391-439.

44 Report on Issues Related to Takover Bids, supra note 18, p. 54.

45 Kaisanlahti, T., supra note 10, p. 498.

46 Ibid.

47 Van der Elst, C. and Van Den Steen, L., supra note 21, p.15.

48 Van der Elst, C. and Van den Steen, L., supra note 7.

49 Ibid., p. 400.

50 Theiss, W. Czech Republic: Squeeze-out Regime. International Financial Law Review. 2006, $25:$ 70-71. 
of the transaction triggering the threshold. Moreover, the Directive allowed for other differences of the legal regulation of the squeeze-outs at the national level (e.g. with regard to the threshold, securities, type of companies, etc.). Eventually, as some authors conclude, it is hard to find any harmonization in the legal framework for the squeezeouts. ${ }^{51}$

According to Article 15(5) of the Directive, in the squeeze-outs, which fall within the scope of the Directive, the squeezed-out minority must be offered the same form of compensation as was offered during the preceding bid or cash (the EU member states are also free to provide that cash must be offered in any case as an alternative). With regard to the corporate squeeze-outs, which fall outside the ambit of the Directive, some EU member states, e.g. Belgium ${ }^{52}$, the Netherlands ${ }^{53}$ and Germany ${ }^{54}$, provide that compensation can be offered in cash only.

Having shortly discussed the available ways to squeeze-out a minority, reflection on legal settings of fair compensation in the squeeze-out context is presented next.

\section{Legal regulation: the "fair" price criterion}

\section{1. "Fair price" and "fair value" in Delaware}

In Delaware law, two different concepts of "fair price" and "fair value" can be distinguished. Minority shareholders in a non-arms length squeeze-out merger (e.g. "long-form merger") are protected by a fiduciary principle, which insures that they get a "fair price" for their shares ${ }^{55}$. The "fair price" relates to the economic and financial considerations of the proposed merger, including relevant factors: assets, market value, earnings, future prospects and any other elements that affect the intrinsic or inherent value of company's stock ${ }^{56}$. As it has been already mentioned, the "fair price" is one of the limbs of the "intrinsic fairness" test ${ }^{57}$, i.e. a minority shareholder can request to evaluate the actions of incumbent management (acting in conflict of interests' situation, i.e. as in a "long-form" merger case) against the "fair price" criterion"

The "fair value" concept is the object of the aforementioned appraisal claims that are the only and ultimate option for shareholders, in case there is no notion of unfair dealing in the transaction ${ }^{59}$. By giving the right to appraisal, the Delaware General Corporation Law (hereinafter - the DGCL) gives a fair-value escape option, which concentrates

51 Van der Elst, C. and Van Den Steen, L., supra note 21, p. 36.

52 Van der Elst, C. and Van den Steen, L., supra note 7, p. 424.

53 Ibid., p. 430.

54 Ibid.

55 Campbell, R. B. Jr. Fair Value and Fair Price in Corporate Acquisitions. North Carolina Law Review. 1999, 78: 101-152, 102 .

56 Weinberger v. UOP, Inc., supra note 40, para. 713.

57 Ibid., para. 710.

58 Campbell, R. B., supra note 55, p. 109.

59 Ibid., p. 111, 112; Hamermesh, L. A. and Wachter, M. L. (2007), supra note 16, p. 9. 
primarily on valuing the company as a going concern ${ }^{60}$ and on its liquidation value ${ }^{61}$. Despite this duality, the basic and leading concept of value under the DGCL is that the stockholders are entitled to be paid for that, which has been taken from them, viz. his proportionate interest in the going concern ${ }^{62}$.

Despite the obvious differences (which have been already addressed above) between the "fair value" (appraisal) and "fair price" (breach of fiduciary duty) proceeding, there also might be useful overlaps, i.e. the expropriated corporate opportunity could be the basis for fairness proceedings for breach of loyalty obligation and, at the same time, if the not taken corporate opportunity is considered as a part of company assets in the fair value proceedings ${ }^{63}$. It is important to note that these two measures have more similarities, namely, they serve the same aim to protect the minority shareholders of a target company and that they both raise serious problems to courts ${ }^{64}$ because of the need to make financial calculation involving complex corporate finance issues ${ }^{65}$. Following that, the determination of the fair value available via appraisal proceedings would anyway include most of the issues that would be raised during the fairness proceedings seeking equitable relief ${ }^{66}$. As this article is not aimed at an elaborate analysis of these two remedies at doctrinal level and seeks to identify more practical aspects of coming to an adequate compensation for dissenting shareholders in the squeeze-outs, for the purposes of this article and simplicity, the term "fair value" would be used to refer to both "fair value" in the appraisal proceedings and "fair price" in breach of fiduciary duty proceedings.

The grounds for determining which value should be considered as "fair" at present derives from the section 262 of the DGCL, where, according to subsection (h) in appraisal proceedings. the Court of Chancery shall determine the fair value of the shares exclusive of any element of value arising from the accomplishment or expectation of the merger or consolidation together with interest, if any, to be paid upon the amount determined to be the fair value. The question of the substance of the "fair value" concept was addressed in Tri-Continental Corp. v. Battye ${ }^{67}$, where it was stated that "the basic concept of value under the appraisal statute is that the stockholder is entitled to be paid for that which has been taken from him, viz., his proportionate interest in a going concern" "68. It should be noted that other cases occasionally describe the concept as the true or "intrinsic" value of the stock that has been taken by the merger ${ }^{69}$. However, it seems to be generally accepted that in both appraisal and breach of fiduciary duty

60 Aronstam, B. R.; Balotti, R. F. and Rehbock, T., supra note 26.

61 Bell v. Kirby Lumber Corp., 413 A.2d 137 (Del. 1980), para. 141.

62 Tri Continental Corp. v. Battye, 74 A.2d 71, (Del. 1950), para. 72.

63 Hamermesh, L. A. and Wachter, M. L. (2007), supra note 16.

64 Campbell, R. B., supra note 55, p. 103 and footnote 9.

65 Ibid., p. 104.

66 Glassman v Unocal Exploration Corp., 777 A. 2d (Del. 2001), para. 247-248.

67 See Tri Continental Corp. v. Battye,supra note 62.

68 Ibid.

69 See Chicago Corp. v. Munds, 172 A. 452, 455-56 (Del. Ch. 1934); see also Roessler v. Sec. Sav. \& Loan Co., 72 N.E.2d 259, 260 (Ohio, 1947). 
proceedings, Delaware courts define the fair price as a going concern value (and not a third-party sale (or liquidation) value $)^{70}$. The proxy of value of plaintiff's shares is "pro rata value of the entire firm as a going enterprise" 71 , therefore, the fair value is minority discounts $^{72}$ free.

The squeeze-out merger creates synergies. Therefore, it should be briefly discussed whether such synergies are included in the legal definition of the "fair value". As it can be derived from the statutory rule ${ }^{73}$, gains arising out of the squeeze-out merger should be excluded from the calculation of the "fair value" at least in appraisal cases, i.e. the merger should be Pareto-efficient (squeezed-out shareholders should not be made worse off $)^{74}$. Notwithstanding the apparent legal certainty of this statutory limitation, some cases suggested that the exclusion is "a very narrow exception to the appraisal process, designed to eliminate use of [..] projections of a speculative variety relating to the completion of the merger" 75 . Accordingly, it seems that the case law suggests drawing a line between "speculative" and "non-speculative" merger-related gains, the latter to be taken into account when deciding on the "fair value" ", but it is not the only opinion. Such a position was criticized as inconsistent and overly broad in the part that non-speculative values should be included in the valuation ${ }^{77}$. Also, there were opinions that all gains, which are the consequence of inside information (especially undisclosed monetary flows), should be included in calculating the fair value of the firm, while other merger gains should not ${ }^{78}$. It should be noted that from the corporate finance perspective all reinvestment opportunities known to the controlling shareholder and being an integral part of its strategy before the squeeze-out should be included in the "fair value" calculations irrespective whether such opportunities where disclosed at the time ${ }^{79}$.

According to the case law, the value of business opportunity wrongfully usurped by the controlling shareholder, which should formally be included in the corporation's assets as a claim - the intangible asset ${ }^{80}$; all fees paid to the controlling shareholder in the breach of fiduciary duty and not at arm's length (e.g. excessive management fees

70 See, e.g., Roenblatt v. Getty Oil Co., 493 A.2d 929 (Del. 1985), para. 942.

71 Kahn v. Tremont Corp., No. Civ. A. 123339, WL 145452, (Del. Ch. Mar. 21, 1996), para. 9.

72 It is generally admitted that control has a value, therefore, it can be assumed that minority shares are worth less than the controlling portfolio (see, e.g., Coates, J. C. "Fair Value" as an Avoidable Rule of Corporate Law: Minority Discounts in Conflict Transactions. University of Pennsylvania Law Review. 1999, 6(147): 1251-1359; Booth, R. A. Minority Discounts and Control Premiums in Appraisal Proceedings. 57 Bus. Law. 2001-2002, 127).

73 Delaware General Corporation Law, supra note 22, Art. 262 (h): "[... the court shall determine the fair value of the shares exclusive of any element of value arising from the accomplishment or expectation of the merger or consolidation [..."”.

74 Easterbrook, F. H. and Fischel, D. R. The Economic Structure of Corporate Law. Harvard: Harvard University Press, 1996, p. 146.

75 Weinberger v. UOP, Inc., supra note 40, para. 713.

76 Cede \& Co. v. Technicolor, Inc., 1990 WL 161084 (Del. Ch., Oct. 19,1990), para. 287.

77 Hamermesh, L. A. and Wachter, M. L. (2007), supra note 16, p. 28.

78 Coffee, J. C. Transfers of Control and the Quest for Efficiency: Can Delaware Law Encourage Efficient Transactions While Chilling Inefficient Ones? Delaware Journal of Corporate Law. 1996, 21: 359-396.

79 Brealey, R. A. Principles of Corporate Finance. 9th edition. 2008, p. 99-102.

80 Cavalier Oil Corp. v. Harnett, 564 A.2d 1137 (Del. 1989). 
paid to the mother company, interest from inter-company loan, etc.) $)^{81}$; benefits of the pre-merger planned activities that would arise in the future as well as other savings arising from the synergy ${ }^{82}$ should be added to the company's assets and, therefore, included in the fair price calculations, provided that, e.g., the savings were contemplated "well before the going private merger", the savings could have been achieved without a merger ${ }^{83}$ and that the pre-existent cause of the savings was an asset of the corporation at the time of the merger (therefore, it should be shared by all shareholders) ${ }^{84}$. However, the situation with the inclusion of synergies in the fair value calculations can be different in the breach of fiduciary duty proceedings, as here court might award the minority shareholders difference between the compensation received for the shares at the time of a squeeze-out and their post-merger price (the date of the court's award), which might reflect all synergies created by the merger ${ }^{85}$.

To summarize, the "fair value" of a share in the squeeze-out is a proportionate part of a firms' (as a going concern) value, which should take account of the current assets of the corporation and the free cash flow generated by those assets and may also include corporations' reinvestment opportunities ${ }^{86}$. Therefore, as some authors claim, the undertaking is not exclusively defined by its present assets, but by the current assets, and it is likely to acquire those assets as part of its current corporate policy ${ }^{87}$. Moreover, it is more or less clear that all gains (synergies) from a transaction do not have necessarily go to the minority shareholders ${ }^{88}$.

\subsection{Fair price in $\mathrm{EU}$}

Legal story of the "fair price" on EU level is significantly shorter that the above presented discussion on the "fair value" in Delaware. According to the Directive, the EU member states have to ensure the "fair" squeeze-out price ${ }^{89}$. The Directive provides that the squeeze-out price shall be presumed to be fair if a bidder, who holds (before or after the bid) $90 \%$ of all capital carrying voting rights of a target ${ }^{90}$, attracts at least $90 \%$ of the targeted capital carrying voting rights ${ }^{91}$. In case of voluntary bids, the bidder can offer any price at his discretion, whereas in case of mandatory bid, the lower price limit

81 Dobler v. Montgomery Cellular Holding Co., Inc, 2004 WL 2271592 (Del. Ch. Sep. 30, 2004).

82 Emerging Communications, Inc. Shareholders Litig., 2004 Del. Ch. LEXIS 56, (Del. Ch. May 3, 2004), para. 47-49.

83 Ibid., para. 48.

84 Ibid., para 49.

85 Gevurtz, F. A. Corporation Law 661. 2000, p. 737.

86 Hamermesh, L. A. and Wachter, M. L. 2007, supra note 16, p. 8.

87 Ibid.

88 Pritchard, A. C., supra note 18, p. 87.

89 European Parliament and Council Directive of 21-04-2004 No. 2004/25/EC ,supra note 42, Art. 15(5): "Member States shall ensure that a fair price is guaranteed."

90 Ibid., Art. 15(2).

91 Ibid., Art. 15(5): "[..]Following a voluntary bid [..]the consideration offered in the bid shall be presumed to be fair where, through acceptance of the bid, the offeror has acquired securities representing not less than 90 per cent of the capital carrying voting rights comprised in the bid". 
is the highest price paid by the bidder for the target's shares within the period prescribed by a Member state ${ }^{92}$.

The Directive does not provide any further explanation if and when the abovementioned presumptions are rebuttable. Some scholars claim that the presumptions of the "fair" price are rebuttable, i.e. can be challenged before courts or the authority supervising the takeover bid in particular circumstances ${ }^{93}$. Some authors, in particular German commentators, argue that the presumptions are not rebuttable ${ }^{94}$. In the author's opinion, though the question whether these presumptions are rebuttable or not could be decided on the national level, it should be agreed that, as some scholars claim, even if the fair price presumptions are rebuttable, it is unlikely that a price considered to be fair by legislator would be prone to extensive judicial review (especially in civil law countries) $)^{95}$.

The Directive makes the squeeze-out right available within 3 months period after a bid. Therefore, it would be logical if the above-defined fairness presumption is lost if the 3 months period is exceeded. Moreover, as some authors claim, the fairness presumption should be rebutted in case some material information would arise after the bid is closed or pre-bid is wrongfully disclosed during the bid information ${ }^{96}$.

Except for the above mentioned cases, the Directive does not provide any guidance on what the "fair price" should be, i.e. the regulation of the "fair price" in other cases, which are not explicitly referred to in the Directive (e.g. the "fair price" in corporate squeeze-outs), are left for the discretion of EU member states. Of course, the EU member states in some cases may introduce additional requirements to those introduced by the Directive, as the Directive only aims at providing minimum level of harmonization. Some authorities suggest that in cases not directly governed by the Directive the "fair price" should be a price determined by the experts ${ }^{97}$.

Some EU member states, e.g. Italy and the Slovak Republic, directly implement provisions of the Directive and always describe a price as fair if it is the price of a mandatory tender offer or a voluntary tender offer with an acceptance rate of $90 \%$ or more $^{98}$. Other countries, e.g. Spain and the United Kingdom, deem the price of the

92 European Parliament and Council Directive of 21-04-2004 No. 2004/25/EC, supra note 42, Art. 5(4): "The highest price paid [..] by the offeror, or by persons acting in concert with him/her, over a period, to be determined by Member States, [..] before the [mandatory] bid [..] shall be regarded as the equitable price".

93 Van der Elst, C. and Van Den Steen, L., supra note 21, p. 32; Van der Elst C. and Van den Steen L., supra note 7, p. 421.

94 Austmann, A. and Mennicke, P. Übernahmerechlicher Squeeze-out und Sell-out. Neue Zeitschrift Für Gesellschaftsrecht. 2004, 846, 851; Krause, H. BB-Europareport: Die EU-Übernahmerichtiline Anpassungsbedarf im Wertpapiererwerbs- und Übernahmegesetz, p. 3; Der Betriebs-Berater. 2004, 113, 118; Schmidt and Lutter. Aktiengesetz Kommentar. Köln, Schmidt, 2008, p. 3030; Geibeland Süssman, Wp $\ddot{U} G$-Kommentar. München, Beck, 2008, p. 704.

95 Ventoruzzo, M., supra note 1, p. 893.

96 Kaisanlahti, T., supra note 10, p. 510-513.

97 Report on Issues Related to Takover Bids, supra note 18.

98 Maul, S. and Muffat-Jeandet, D. The Directive on Takeover Bids, in: Takeover Bids in Europe: The Takeover Directive and Its Implementation in the Member States. Maul, S. et al., eds., 2008, p. 416. On the Slovak Republic, see Hazucha, B. and Jurková, M. Slovak Republic, in: Common Legal Framework for Takeover Bids in Europe. Van Gerven, D., ed., 2008, p. 375. 
voluntary or mandatory tender offer price "fair" for the squeeze-out purposes only if at least $90 \%$ of all targeted shares are acquired during the tender offer ${ }^{99}$. The rationale to depart from the basic rules of the Directive, as some authors suggest, is the provision of the higher level protection for the minority shareholders ${ }^{100}$.

It seems that regarding the EU member states level, the "fair price" outside the cases prescribed in the Directive is the price determined by independent experts (e.g. Germany ${ }^{101}$ ), the price determined by the independent experts and later approved by administrative authority (e.g. Belgium ${ }^{102}$, France ${ }^{103}$ ) or determined by administrative authorities (e.g. the Netherlands ${ }^{104}$ ). As the case may be, the "fair" price is also an object of appraisal disputes settled by courts under the request of minority (e.g. the UK ${ }^{105}$, Italy ${ }^{106}$ ) or administrative authority (e.g. France). Most of the EU member states fail to give an exact standard of value, which would be considered as "fair" (or at least scholarly literature or commentaries discussing these standards in English are absent), however, it seems that some countries define the "fair value" as "real value" of shares at the time of transfer (e.g. the Netherlands ${ }^{107}$ ).

\section{Which price could be considered as "fair"?}

In both common law and civil law jurisdictions the same three main valuation standards are recognized to (optionally) determine the fair value in squeeze-out transactions, i.e. third party sale (liquidation) value, going concern value and market value $^{108}$ (although, additionally, some authors claim that the appropriate standard might be the combination of all these values ${ }^{109}$ ). The relevancy of each particular standard is case specific and dependant on legal setting of the squeeze-out compensation.

\subsection{Market value}

The proponents of the market value as an appropriate benchmark for the fair squeeze-out compensation relies on the assumption that financial markets are efficient

99 Ventoruzzo, M., supra note 1, p. 899.

100 Ibid., p.898.

101 Van der Elst, C. and Van Den Steen, L., supra note 21, p. 22-23.

102 Van der Elst, C. and Van den Steen, L., supra note 7, p. 424.

103 Van der Elst, C. and Van Den Steen, L., supra note 21, p. 33.

104 Ibid., p. 34.

105 Ibid., p. 29.

106 Ventoruzzo, M. Cross-Border Mergers, Change of Applicable Corporate Laws and Protection of Dissenting Shareholders: Withdrawal Rights under Italian Law. 4 Eur. Company \& Fin. L. Rev. 2007, 47: 62.

107 Van der Elst, C. and Van den Steen; L., supra note 7, p. 429.

108 Hamermesh, L. A. and Wachter, M. L. (2009), supra note 16, p. 1022.

109 Hunter, C. and Potter, K. Legal and Practical Issues for Business Valuation in Shareholders Agreements and Minority Shareholders Rights. Presentation [interactive]. [accessed on 11-08-2011]. <http://www.macleoddixon.com/documents/Business_Valuation_in_Shareholders_Agreements_and_Miniority_Shareholder_Rights.pdf>. 
and, therefore, value of securities in the markets are the best objective measure of the fair value ${ }^{110}$, e.g., some authors claim that market prices might be a proxy for the fair value even in cases of illiquid shares (despite existent illiquidity discount) when control is absent ${ }^{111}$. It can be admitted that in some countries (under specific circumstances) the market price is actually considered as a measure of the fair value, i.e. the market price is considered as the "floor" of the squeeze-out price in Germany"12 or arithmetical average of the market prices of a target within a specific period of time is considered as an appropriate measure of the fair price in Italy ${ }^{113}$ and Spain ${ }^{114}$. The market price is also one of the elements accounted for in the French 'multi-criterion' approach ${ }^{115}$.

However, it is now widely admitted that the market price cannot serve as a benchmark for coming to the fair value in most of the situations, when the fair price is determined, e.g., because of the illiquidity (thin trading and absence of marketability) as a market value may be discounted relative to the value of the undertaking ${ }^{116}$. Moreover, efficient markets might value shares according to the plans of a controller ${ }^{117}$ and in case there are reasons to believe that the controller might use the company to extract private benefits, under-manage the firm (because in such a case the effect of the market for corporate control is absent) ${ }^{118}$ or in other ways seek to gain additional profits while avoiding legal supervision, the market price of the shares would be discounted accordingly ${ }^{119}$. Under such settings, the controller would be rewarded for abusive and opportunistic behavior, therefore, as some authors claim, this reason alone is sufficient to prove that the market price cannot be a measure of the fair value ${ }^{120}$. Alternatively, the market price might fail to reflect the fair price (or at least the current price) of the securities as a majority shareholder can plan the timing of a squeeze-out and usually would choose the moment, when the market price is depressed ${ }^{121}$. Also, the market price might not represent the fair value in the squeeze-outs because it may be discounted for the very possibility of a squeeze-out ${ }^{122}$.

110 Bebchuk, L. A. and Kahan, M. Adverse Selection and Gains to Controllers in Corporate Freezeouts, in: Concentrated Corporate Ownership. Morck, R. K., ed., 2000.

111 See, e.g., Kraakman, R. Taking Discounts Seriously: The Implications of "Discounted" Share Prices as an Acquisition Motive. 88 Columbia Law Review. 1998: 891.

112 Elsland, S. and Weber, M., supra note 4, p. 4.

113 Ventoruzzo, M., supra note 1, p. 885.

114 Ibid.

115 Van der Elst, C. and Van den Steen, L., supra note 7, p. 426.

116 Coates, J. C., supra note 72, p. 1262.

117 Hamermesh, L. A. and Wachter, M. L. (2009), supra note 16, p. 1032.

118 Hamermesh, L. A. and Wachter, M. L. (2007), supra note 16, p. 14.

119 Bebchuk, L. A. and Kahan, M., supra note 110, p. 247, 250.

120 Hamermesh, L. A. and Wachter, M. L. (2009), supra note 16, p. 1035.

121 Ventoruzzo, M., supra note 1, p.886.

122 Gevurtz, F. A., supra note 85, p. 736; Bebchuk, L. A. and Kahan, M. The "Lemons Effect” in Corporate Freeze-Outs. Nat'l Bureau of Econ. Research, Working Paper No. 6938, 1999 [interactive]. [accessed on 11-08-2011]. <http://papers.ssrn.com/sol3/papers.cfm?abstract_id=226397>. 
On the other hand, some authors suggest that a minority might engage in practices that would increase the market price of the shares in hope of receiving higher compensation $^{123}$.

It follows that in most of the cases the market price could not be considered as a proxy of the fair price in the squeeze-outs because of the inherent risks to undercompensate or over-compensate the minority.

\subsection{Third party sale value}

The third-party sale value or the liquidation value seems to match the economic definition of value (measured by the "second best use" of a particular asset) ${ }^{124}$. However, as the third-party sale value relies on the prices of similar transactions that include synergies generated by those transactions ${ }^{125}$, it is rejected as an inappropriate measure of the fair value by Delaware courts because the legal regulation (which has been already discussed above) rules out incorporation of merger-specific synergies in the calculations of the fair price in the squeeze-out transactions, i.e. the minority shareholders do not have a right to claim for the value that might be obtained in the simulated third-party sale transaction ${ }^{126}$. Neither at EU level, nor at EU member states level it is explicitly stated whether squeeze-out related gains should be included or excluded from the calculations of the fair price (in some cases, this discussion, at least as some authors suggest ${ }^{127}$, would be irrelevant as the major part of the synergies is related with the aggregation of control, which in some cases is already apparent before the squeeze-out price is determined, therefore, it should be included in its calculation). However, in any case the third-party sale value criterion due to excessive compensation for the expropriated shares might deter efficient takeovers. Additionally, the introduction of the third-party sale value criterion might encourage the controller to act opportunistically, i.e. to time a squeezeout when acquisition price ratios are unusually low and rely on such deflated ratios to justify a fair value that would be lesser than the fair value of expropriated shares ${ }^{128}$.

As it has been already mentioned, it is explicitly unclear whether the EU level legal regulation allows including the synergies created by a takeover into the calculation of the squeeze-out compensation, i.e. whether use of the third-party sale criterion is available from a legal perspective. As it has been discussed above, the price of a mandatory bid is considered fair by the Directive. The price of the mandatory bid is set at the price of the mandatory bid triggering transaction, which is usually a price paid for control. Gains arising from accumulation of control are genuine ex-merger gains. Therefore, it might be assumed that at least in the case of post mandatory bid squeeze-outs, the Directive allows including elements of value arising out of the takeover in the fair value. It might

123 Steinmeyer, R. and Häger, M. Wp ÜG: Kommentar zum Wertpapiererwerbs- und Über-nahmegesetz mit Erläuterungen zum Minderheitenausschluss nach \$\$327a ff. AktG. Berlin, 2002.

Brealey, R. A., supra note 79, p. 535-537. 
be further assumed that such ex-merger gains by analogy could be included in the fair price calculations in other cases, as well. Therefore, the third-party sale value (at least theoretically) should not be completely excluded.

\subsection{Going concern value}

The going concern value is probably the most widely established concept to measure the fair price in the squeeze-outs ${ }^{129}$. Moreover, it is the standard used by Delaware courts in appraisal cases and is generally understood as preceding over the liquidation (third party sale) value ${ }^{130}$ due to the above-discussed reasons. Nevertheless, use of the going concern value criterion, which is usually calculated by using discounted cash flow analysis (hereinafter - the DCF), in some cases might create unfair results e.g., in Bell v. Kirby Lumber Corp. case, court refused to exclusively rely on the liquidation value as a proxy for the fair value (as a consequence, shareholders received $254.4 \$$ per share, when the liquidation value of assets was at least $456 \$$ ). It is obvious that under appropriate management the going concern value would have been equal of higher than company's assets value. Another case, which is more specific for Delaware, where ex-merger gains are excluded from the fair value calculations, is when due to unavailability/unreliability of relevant data a comparable company analysis is used to estimate the going concern value $^{131}$. Some authors suggest that the use of the comparable company analysis creates information asymmetries due to undisclosed reinvestment opportunities, etc., and, therefore, might lead to under-compensation of the minority ${ }^{132}$. On the other hand, it might over-compensate the minority because the data (prices) retrieved from similar transactions include synergies, which are deprived from (at least Delawares' companies) the minority shareholders.

Methods used to determine the fair value are more elaborately discussed in the further section of this paper.

\section{How the "fair price" is determined?}

Courts of one of the most prominent (at least as far as in the concerned squeeze-outs) jurisdiction (Delaware) as early as in 1983 admitted that the fair value can be measured by any methods recognized by the financial community ${ }^{133}$. It seems that at least some European jurisdictions adopt the same approach, as well (e.g. the Netherlands, where court is free to choose the method for the fair price calculation on its own discretion) ${ }^{134}$. In addition, some European jurisdictions (though it is not a generally accepted rule), e.g.

\footnotetext{
129 Campbell, R. B., supra note 55, p. 118.

130 Ibid., p. 119.

131 Hamermesh, L. A. and Wachter, M. L. (2009), supra note 16, p. 1037, 1044.

132 Ibid., p. 1037, 1061.

133 Weinberger v. UOP, Inc., supra note 40.

134 Van der Elst, C. and Van den Steen, L., supra note 7, p. 429.
} 
Belgium (as some authors suggest) ${ }^{135}$, require the use of at least two methods to prove the fairness of a squeeze-out price. It also should be noted that the use of one of the commonly accepted financial techniques might not be the case as some EU jurisdictions (e.g. Spain and Italy) ${ }^{136}$ employ the use of methods solely based on an arithmetical average of the market prices of a particular share within a particular time frame.

Despite the relatively wide selection of possible methods for measuring fair compensation in the squeeze-out transactions, the most popular methods can be identified. As it can be derived from the scholarly literature and other sources (case law, etc.), the most commonly used methods are the 'block approach', comparable company analysis and DCF analysis.

It should be noted that even a price determined by an appropriate method may not be the appropriate squeeze-out price, as in some jurisdictions it may be adjusted upwards to compensate for the minority, illiquidity and other discounts.

The above referred most widely used methods and price adjustments are addressed below.

\subsection{The 'block approach'}

The so called 'block approach' or 'multi-criterion approach' generally refers to the technique, which calculates the fair price of a squeeze-out by arithmetical or weighted average of different multiples, e.g. market price, value of company's assets, past earnings, etc.

Till the above-mentioned Weinberger case, the block method, which, where possible, took into account weighted average (weight to a particular part varied with the circumstances of the case) value of company's assets, market price of its shares and value of its earnings, was an exclusively dominating method for the determination of fair or intrinsic value of the share in Delaware ${ }^{137}$. However, after Weinberger, it was replaced by other more modern finance theory compatible methods (mainly, the DCF).

Similarly to the method, which was applied by Delaware courts in the preWeinberger, France administrative authorities call for the squeeze-out price to be determined by combining (depending on the relevance of each particular in specific case) value of targets' assets, share trading price, historical performance data, existence of subsidiaries and future prospects ${ }^{138}$.

Some similarities can also be found in German techniques, where the fair price is determined by combining the valuation of a target company (usually the DCF or net

135 Ibid., p. 424.

136 Ventoruzzo, M., supra note 1, p.885-886.

137 Weinberger v. UOP, Inc., supra note 40, para. 712.

138 Van der Elst, C. and Van den Steen, L., supra note 7, p. 426. 
present value of the net profits accrued to the shareholders) and market price of targets' shares $^{139}$.

\subsection{Comparable company analysis}

The comparable company analysis is a method, which employs financial rations (e.g. deal price/earnings, enterprise value/equity before interest taxes and amortization, etc.) of comparable companies to determine the value of a target company.The comparable company analysis is usually used when there is insufficient data for the DCF analysis or where the latter would be not suitable.As some authors claim ${ }^{140}$, the squeeze-out price determined by the comparable company analysis (unless in cases when control of a target company is acquired by a bidder beforehand $)^{141}$ is not in line with the legal framework of Delaware, as the fair price in this jurisdiction excludes any synergies from the transaction, whereby the price determined by the comparable company analysis (using rations from other controlled-aimed transactions) accounts for the control premium.

Usually, the comparable company analysis relies on historical data to measure financial standing of a company ${ }^{142}$. The comparable company analysis does not take controllers' future plans for the target into consideration, therefore, such plans remain hidden from the minority shareholders (creating information asymmetry) ${ }^{143}$ and the value of the target company does not account for the present value of such plans.

\subsection{The DCF}

When using the DCF analysis, the present value of a particular asset is determined by calculating the future cash flows that would be generated by the asset and discounting such flows with predetermined discount rates $^{144}$, i.e. the analysis entails three basic components: 1) an estimation of net cash flows that the firm will generate and when it will do so; 2) a terminal or residual value equal to the future value; and 3) a cost of capital, with which to discount to present value both the projected net cash flows and the estimated terminal or the residual value ${ }^{145}$.

Though the DCF is a widely accepted and used method in the EU ${ }^{146}$ and the first choice method to determine firms' value in Delaware after the Weinberger case, as well as in corporate finance theory, it raises two uncertainties towards the calculation of the

139 Ibid., p. 430.

140 Hamermesh, L. A. and Wachter, M. L. (2009), supra note 16.

141 Ibid., p. 1037, 1053.

142 See Eisenhofer, J. W. and Reed, J. L. Valuation Litigation. 22 Delaware Journal of Corporate Law. 1997, 37: 116-119.

143 Hamermesh, L. A. and Wachter, M. L. (2009), supra note 16, p. 1037, 1061

144 Onti,Inc. v. Integra Bank, 751 A.2d 904, 912 (Del.Ch. 1999).

145 Aronstam, B. R.; Balotti, R. F. and Rehbock, T., supra note 26, p. 545 and supra note 199.

146 Van der Elst, C. and Van den Steen, L., supra note 7, p. 430. 
cash flows and the selection of appropriate discount rates ${ }^{147}$. Such uncertainty can lead to competing valuation results ${ }^{148}$.

The DCF method also might represent inaccurate results when used to determine value of concerns involved in financial activities, as it will not account for the necessity to capitalize equity based on regulatory and other requirements.

\subsection{Minority discount and share price adjustments}

Case law and legal acts (or at least recommendations published by administrative authorities) of Delaware and some EU member states suggest that the determined price of a squeeze-out should be adjusted upwards because the determined price of a targets' shares is discounted for lack of control (e.g. the right to appoint management, etc.). Such position derives from the assumption that a corporation and its shares are separate items, as shares provide only limited rights over the corporation and thus do not represent the complete value of the corporation itself ${ }^{149}$.

For instance, following the above indicated approach, the courts of Delaware attempted to adjust the valuation for a minority discount by adding back a premium "that spreads the value of control over all shares equally..." ${ }^{150}$. This concept of implicit minority discount was deeply criticized by Delaware scholars as incompatible with the modern theory of corporate finance (which proclaims that the market price of a share reflects pro rata value of corporation's discounted net cash flows) ${ }^{151}$ as well as incompatible with statutory requirements, which exclude any merger-related gains from the fair price in appraisal in cases, where a squeeze-out merger is a transaction to gain control $^{152}$.

In EU jurisdictions, in both post-bid squeeze-outs and take-over squeeze-outs the controller enjoys a sufficient level of control, therefore, the above referred discussion on Delaware case law is irrelevant because the value of control is already included in the value of the target and should be equally shared by all shareholders (at least so far as the standard for the fair price in the squeeze-out is a proportionate part in a going concern).

It should be noted that there are also other cases, when the controller can exploit its position and mismanage the target in order to depress the value of shares by avoiding paying the fair price for the expropriated shares ${ }^{153}$. In such cases, which are relevant for both Delaware and EU member states, the same commentators agree that the price should be adjusted upwards; however, they assume that other more finance-compatible

147 Weston, J. F.; Mitchell, M. L. and Mulherin, J. H. Takeovers, Restructuring, and Corporate Governance. 4th edition. Upper Saddle River, NJ: Pearson Prentice Hall, 2004, p. 232-255.

148 Cox, J. D.; Hillman, R. W. and Langevoart, D. C. Securities Regulation-Cases and Materials. 4th edition. Gaithersburg: Aspen Publishers, 2004, p. 99.

149 See, e.g., Gordon, J. N. and Kornhause, L. A. Efficient Markets, Costly Information, and Securities Research. 60 N.Y.U. L. Razv. 1985, 761, 825.

150 Agranoff v. Mille, 791 A.2d 880, 887 (Del. Ch. 2001).

151 Hamermesh, L. A. and Wachter, M. L. (2007), supra note 16, p. 49.

152 Hamermesh, L. A. and Wachter, M. L. (2009), supra note 16, p. 1037, 1052.

153 Hamermesh, L. A. and Wachter, M. L. (2007), supra note 16, p. 6-7. 
techniques than adding a compensation for illusive 'minority discount' should be used when defining the going concern value instead of a theoretically unsupported implicit minority discount ${ }^{154}$.It is suggested that the earnings or cash flows of a target impaired by the mismanagement by a controller can be cured by adjusting the earnings or cash flows of the target upwards ${ }^{155}$.

\section{Conclusions}

Notwithstanding the fact whether compensation in squeeze-outs is referred to as a "fair" price of shares, a proportionate part in a going concern or the real price of shares at the time of a squeeze-out, the extent to which minority is compensated is mainly dependent on the standard of value and the methodology to calculate such value employed. Minority shareholders should receive any and all elements of value inherent in a target company at the time of the squeeze-out. However, the minority shareholders should not get a part of value created by a majority shareholder. In any case, it should be noted that shares of a company may be discounted relative to the value of the undertaking. Therefore, an appropriate value of shares should be a proportionate part of company's value, which, on its own turn, should be valued as a going concern employing its present assets and pre-planned reinvestment opportunities, unless such a standard for compensation would clearly mean unjust results.

Use of majority of minority rule modifications can strike a right balance between the interests of minority and majority shareholders. However, qualitative differences in between required thresholds of minority shareholders' approval in the US and in the EU post-bid squeeze-outs introduced by the Directive seem to stress different goals, i.e. the former being minority/majority neutral, whereas the latter introducing pro-minority settings. Following that, the fair price presumption (i.e. that the price accepted by $90 \%$ of the minority shareholders is fair) introduced by the Directive should be considered as not rebuttable.

Unlike in Delaware, the EU level legal framework introduced by the Directive suggests that squeeze-out specific synergies should be included in fair price calculations. It seems so because a mandatory-bid price, which normally is a price including premium for control, is presumed to be fair. One might assume that EU member states, which introduce the squeeze-outs in other cases than prescribed in the Directive, would retain a similar level of protection for the minority shareholders to that provided by the Directive in post mandatory bid squeeze-outs cases. As compensation paid for the minority shareholders seems to be more than sufficient (or even of over-compensating nature) in the post-mandatory bid squeeze-outs, the presumption defined in the Directive should be not rebuttable and national squeeze-outs following the same approach towards compensation should introduce similar assumptions. 
One could question whether the squeeze-out price, which is set at the price of the mandatory bid (which, on its own turn, is usually set at the level of price paid to gain control of a target), can be considered as fair with respect interests of the controller, as he is the one (not the target company) who concentrated control and, therefore, reap the benefits it offers. However, it should be admitted that at the time of post-bid squeeze-out control is also a part of company's assets, therefore, it should be shared by all shareholders, notwithstanding the fact that the minority did not do anything to aggregate it.

When deciding on fair compensation for the dissenting shareholder, target's assets, market value of target's shares, its earnings, future prospects and any other elements might be taken into consideration. However, use of particular variables and their weight highly depends on the method or methods used. It seems to be widely accepted to rely on any of methods that are accepted by the finance community. Such a practice should be welcomed, as there is not a single method, which would be suitable for all cases. More specifically, it seems to be appropriate to rely on several methods, however, it should be an exception applied only in a very limited number of cases, when the date for one of the methods is unreliable.

Minority over-compensating measures (various minority-discounts curing measures shifting a squeeze-out price upwards) should be applied only in cases, when there is evidence of opportunistic behavior on behalf of a controlling shareholder (i.e. intentional mismanagement, failure to disclose material information) and only indirectly, i.e. by adjusting cash flows or awarding damages.

\section{References}

Abrams, K. G. and Laster T. New Delaware Rules for Going Private Transactions. Insights. 2005, 19(7): 9-13.

Agranoff v. Mille, 791 A.2d 880, 887 (Del. Ch. 2001).

Aronstam, B. R.; Balotti, R. F. and Rehbock T. Delaware's Going Private Dilemma: Fostering Protections for Minority Shareholders in the Wake of Siliconix and Unocal Exploration. Business Lawyer. 2003, 58: 519-558.

Austmann, A. and Mennicke, P. Übernahmerechlicher Squeeze-out und Sellout. Neue Zeitschrift Für Gesellschaftsrecht. 2004, 846, 851.

Bebchuk, L. A. and Kahan, M. Adverse Selection and Gains to Controllers in Corporate Freezeouts, in: Concentrated
Corporate Ownership. Morck, R. K., ed., 2000.

Bebchuk, L. A. and Kahan, M. The "Lemons Effect" in Corporate Freeze-Outs. Nat'l Bureau of Econ. Research, Working Paper No. 6938, 1999 [interactive]. [accessed on 11-08-2011]. <http://papers.ssrn.com/sol3/ papers.cfm?abstract_id=226397>.

Bell v. Kirby Lumber Corp., 413 A.2d 137 (Del. 1980).

Booth, R. A. Minority Discounts and Control Premiums in Appraisal Proceedings. 57 Bus. Law. 2001-2002, 127.

Brealey, R. A. Principles of Corporate Finance. 9th edition. 2008.

Burkart, M. and Panunzi, F. Law working paper No 10/2003: Mandatory Bids, Squeeze-out, Sell-out and the Dynamics of the Tender Offer Process. 2003, Stockholm Institute of 
Transitional Economics \& Departament of Finance, Stockholm School of Economics and CEPR [interactive]. [acessed on 10-082011]. <http://ssrn.com/abstract=420940>.

Campbell, R. B. Jr. Fair Value and Fair Price in Corporate Acquisitions. North Carolina Law Review. 1999, 78: 101-152.

Cavalier Oil Corp. v. Harnett, 564 A.2d 1137 (Del. 1989).

Cede \& Co. v. Technicolor, Inc., 1990 WL 161084 (Del. Ch., Oct. 19, 1990).

Chicago Corp. v. Munds, 172 A. 452, 455-56 (Del. Ch. 1934).

Coates, J. C. "Fair Value" as an Avoidable Rule of Corporate Law: Minority Discounts in Conflict Transactions. University of Pennsylvania Law Review. 1999, 147(6): 1251-1359.

Coffee, J. C. Transfers of Control and the Quest for Efficiency: Can Delaware Law Encourage Efficient Transactions While Chilling Inefficient Ones? Delaware Journal of Corporate Law. 1996, 21: 359-396.

Cox, J. D.; Hillman, R. W. and Langevoart, D. C. Securities Regulation - Cases and Materials. 4th edition. Gaithersburg: Aspen Publishers, 2004.

Delaware General Corporation Law [interactive]. [accessed on 10-08-2011]. $<$ http://delcode.delaware.gov/title8/c001/ index.shtml - P-1_0>, Art. 251.

Dobler v. Montgomery Cellular Holding Co., Inc., 2004 WL 2271592 (Del. Ch. Sep. 30, 2004).

Easterbrook, F. H. and Fischel, D. R. The Economic Structure of Corporate Law. Harvard: Harvard University Press, 1996, p. 146.

Eisenhofer, J. W. and Reed, J. L. Valuation Litigation. 22 Delaware Journal of Corporate Law. 1997, 37.

Emerging Communications, Inc. Shareholders Litig. 2004 Del. Ch. LEXIS 56, (Del. Ch. May 3, 2004).

Elsland, S. and Weber, M. Squeezeouts in Germany: Determinants of the Announcement Effects [interactive]. [accessed on 10-08-2011] <http://www.unituebingen.de/dgf/program/CPaper137.pdf $>$.

European Parliament and Council Directive of 21-04-2004 No. 2004/25/EC on Takeover Bids. OJ L. 2004, 142: 12-23.

Furlow, C. V. Back to Basics: Harmonizing Delaware's Law Governing Going Private Transactions. 40 Akron L. Rev. 2007, 85.

Gevurtz, F. A. Corporation Law 661. 2000, p. 737.

Gilson, R. J. and Gordon, J. N. Controlling Controlling Shareholders. University of Pennsylvania Law Review. 2003, 152(785): 785-843.

Glassman v Unocal Exploration Corp. 777 A. 2d (Del. 2001).

Hamermesh, L. A. and Wachter, M. L. Rationalizing Appraisal Standards in Compulsory Buyouts. 50 B.C. L. Rev. 2009: 1021-1068.

Hamermesh, L. A. and Wachter, M. L. The Short and Puzzling Life of the Implicit Minority Discount. 156 U. Pa. L. Rev. 20072008, 2: 1-61.

Hunter, C. and Potter, K. Legal and Practical Issues for Business Valuation in Shareholders Agreements and Minority Shareholders Rights. Presentation [interactive]. [accessed on 11-08-2011]. <http://www. macleoddixon.com/documents/Business Valuation_in_Shareholders_Agreements_ and_Miniority_Shareholder_Rights.pdf $>$.

Hunter, C. and Potter K. Legal and Practical Issues for Business Valuation in Shareholders Agreements and Minority Shareholder Rights. Paper presented to the Canadian Institute of Chartered Business Valuators Calgary Chapter on October 0 [wrong day], 1997 [interactive]. [accessed on 10-08-2011]. <http://www.macleoddixon. com/documents/Business_Valuation_in_ Shareholders_Agreements_and_Miniority_ Shareholder_Rights.pdf $>$.

Hazucha, B. and Jurková, M. Slovak Republic, in: Common Legal Framework for Takeover Bids in Europe. Van Gerven, D., ed., 2008. Iacono, C. Tender Offers and Short-Form Mergers by Controlling Shareholders 
Under Delaware Law: The '800-Pound Gorilla' Continues Unimpeded - In re Pure Resources, Inc., Shareholders Litigation. Delaware Journal of Corporate Law. 2003, 28: 645-689.

In re Siliconix Inc. Shareholders Litigation, No. CV-A-18700, 2001 WL 716787 (Del. Ch. June 19, 2001).

Gordon, J. N. and Kornhause, L. A. Efficient Markets, Costly Information, and Securities Research. 60 N.Y.U. L. Razv. 1985, 761, 825.

Kahn V. Tremont Corp., No. Civ. A. 123339, WL 145452, (Del. Ch. Mar. 21, 1996).

Kaisanlahti, T. When Is a Tender Price Fair in the Squeeze-out? European Business Organization Law Review. 2007, 8: 497519.

Lehn, K. and Poulsen, A. Free Cash Flow and Stockholder Gains in Going Private Transactions. 44 J. Fin. 1989, 771.

Kraakman, R. et al. The Anatomy of Corporate Law: A Comparative and Functional Approach. Oxford: Oxford University Press, 2004.

Kraakman, R. Taking Discounts Seriously: The Implications of "Discounted" Share Prices as an Acquisition Motive. 88 Columbia Law Review. 1998.

Krause, H. BB-Europareport: Die EUÜbernahmerichtiline-Anpassungsbedarf im Wertpapiererwerbs- und Übernahmegesetz. Der Betriebs-Berater. 2004, p. 113, 118.

McMullin v. Beran, 765 A.2d 910, (Del. 2000), para. 919-920.

Onti, Inc. v. Integra Bank, 751 A.2d 904, 912 (Del.Ch.1999).

Pinto, A. R. and Branson, D. M. Understanding Corporate Law. 2nd edition. New York: M. Bender, 2004.

Pritchard, A. C. Tender Offers by Controlling Shareholders: The Spectre of Coercion and Fair Price. Berkeley Business Law Journal. 2004, 1(83): 83-111.

Subramanian, G. Fixing Freezeouts. Yale Law Journal. 2005, 115: 2-70.

U.N. Conference on Trade and Development. World Investment Report 2006. FDI from Developing and Transition Economies:
Implication for Development. 2006 [interactive]. [accessed on 10-08-2011]. $<$ http://www.unctad.org/en/docs/wir2006 en.pdf>.

Van der Elst, C. and Van den Steen, L. Balancing the Interests of Minority and Majority Shareholders: A Comparative Analysis of Squeeze-out and Sell-out Rights. ECFR 4/2009, p. 391-439.

Van der Elst, C. and Van Den Steen, L. Working paper: Opportunities in the $M \& A$ Aftermarket: Squeezing out and Selling out. Financial Law Institute, University Gent, 2006.

Ventoruzzo, M. Freeze-Outs: Transcontinental Analysis and Reform Proposals. Virginia Journal of International Law. 2010, 50(4): 842-917.

Rathausky, U. Squeeze-out in Deutschland: Eine Empirische Untersuchung zu Anfechtungsklagen und Spruchverfahren, Die Aktiengesellschaft, R24-R26. 2004.

Report of the High Level Group of Company Law Experts on Issues Related to Takover Bids. 10 January, 2002, Brussels [interactive]. [accessed on 10-08-2011]. $<$ http://ec.europa.eu/internal_market/ company/docs/takoverbids/report_en.pdf $>$.

Regner, W. D. Going Private in the US. International Financial Law Review, Supplement: The 2006 Guide to Mergers and Acquisitions. 2006 [interactive]. [accessed on 10-08-2011]. <http://www.iflr.com/?Pag $\mathrm{e}=17 \&$ ISS $=21679 \& \mathrm{SID}=624573>$.

Roenblatt v. Getty Oil Co., 493 A.2d 929 (Del. 1985).

Roessler v. Sec. Sav. \& Loan Co., 72 N.E.2d 259, 260 (Ohio 1947).

Schmidt and Lutter. Aktiengesetz Kommentar. Köln, Schmidt, 2008, p. 3030; Geibeland Süssman. $W p \ddot{U} G-$ Kommentar. München, Beck, 2008.

Maul, S. and Muffat-Jeandet, D. The Directive on Takeover Bids, in: Takeover Bids in Europe: The Takeover Directive and Its Implementation in the Member States. Maul, S. et al., eds., 2008. 
Steinmeyer, R. and Häger, M. $W p \ddot{U} G$ : Kommentar zum Wertpapiererwerbs- und Über-nahmegesetz mit Erläuterungen zum Minderheitenausschluss nach $\$ \$ 327 a \mathrm{ff}$. AktG. Berlin, 2002.

Ventoruzzo, M. Cross-Border Mergers, Change of Applicable Corporate Laws and Protection of Dissenting Shareholders: Withdrawal Rights under Italian Law. 4 Eur. Company \& Fin. L. Rev. 2007, 47: 62.

Theiss, W. Czech Republic: Squeeze-out Regime. International Financial Law Review. 2006, 25: 70-71.
Tri Continental Corp. v. Battye, 74 A.2d 71, (Del. 1950).

Weinberger v. UOP, Inc., 457 A.2d 701 (Del. 1983).

Weston, J. F.; Mitchell, M. L. and Mulherin, J. H. Takeovers, Restructuring, and Corporate Governance. 4th edition. Upper Saddle River, NJ: Pearson Prentice Hall, 2004, p. 232-255.

\section{TEISINGA PRIVALOMO AKCIJŲ PARDAVIMO KAINA}

\section{Feliksas Miliutis}

Mykolo Romerio universitas, Lietuva

Santrauka. Privalomas akciju pardavimas yra suprantamas kaip situacija, kurioje didysis akcininkas pasinaudoja savo teise privalomai išpirkti smulkiuju "taikinio "imonès akcininku akcijas ir taip „išimti“ "taikinio" imonès akcijas iš prekybos reguliuojamoje rinkoje. Šiame straipsnyje aptariama privalomo akciju pardavimo kompensacijos tema tiek iš ES, tiek iš JAV (Delavero) teisés pozicijų. Nors priežastys „ǐ̌imti“ akcijas iš viešos prekybos tiek ES, tiek JAV iš esmès yra tapačios, büdai igyvendinti privalomo akciju pardavimo teise skiria iš esmès. Nepaisant skirtingu büdu pasinaudoti privalomo akciju pardavimo teise, ES ir JAV jurisdikcijose vyrauja iš esmés vienodas požiūris i standartus ir metodus, naudojamus teisingai privalomo akciju pardavimo kainai nustatyti.

Šio straipsnio autorius laikosi pozicijos, jog nepaisant kiekvienoje šalyje ittvirtintu skirtingu taisykliu teisingai privalomo akciju pardavimo kainai nustatyti, galima identifikuoti bendras tendencijas, kurios, savo ruožtu, pades nustatyti pagrindines praktikoje ir teorijoje kylančias didžiojo ir smulkiuju akcininku apsaugos problemas, kiek tai susije su teisingos kainos nustatymu. Skirtingi su adekvačios privalomo akciju pardavimo kompensacijos nustatymu susije konceptai, tokie kaip "teisinga verte", "proporcinga dalis veikianciame versle“, ar "teisinga kaina“ ir kiti teisinio reguliavimo elementai, pavyzdžiui taisykles, reglamentuojančios iš sandorio kylančios pridetinès vertès paskirstyma, standartai ir metodai, naudojami tinkamai privalomo akciju pardavimo kainai nustatyti, yra sutinkami visose jurisdikcijose. Visgi, ju turinys ir samprata gali büti skirtingi.

Visuotinai pripažistama, jog teisingos kainos standartu paprastai yra laikomas "veikiančio verslo vertès" standartas. Visgi, dèl teisinio reguliavimo ypatumu gali büti ir kitaip.

Daugelyje jurisdikciju privalomo akciju pardavimo kainai nustatyti naudojamu metodu pasirinkimas nèra ribojamas. Nepaisant to, daugelyje šaliu pagrindiniai šiuo tikslu 
naudojami metodai yra piniginiu srautu diskonto ir lyginamosios analizes metodai. Bet kuriuo atveju, konkretaus metodo ar kitu techniku (kainos pakeilimas, mažumos dangumos taisykles ir pan.) naudojimas atitiks didžiojo ir smulkiuju akcininku interesus tik tada, kai šos technikos ar metodai bus priimtini teisinés bazés požiüriu ir tinkami atsižvelgiant i konkrečias faktines aplinkybes.

Reikšminiai žodžiai: privalomas akciju pardavimas, perémimo pasiūlymas, teisinga kaina, teisinga verte.

Feliksas Miliutis, Mykolo Romerio universiteto Teisès fakulteto Verslo teisės katedros doktorantas. Mokslinių tyrimų kryptys: įmonių teisè, konkurencijos teisè.

Feliksas Miliutis, Mykolas Romeris University, Faculty of Law, Department of Commercial Law, $\mathrm{PhD}$ candidate. Research interests: Company Law, Competition Law. 